\title{
THE RHETORIC OF FRIEDMAN'S QUANTITY THEORY MANIFESTO
}

\author{
Thomas Mayer
}

Working Paper Series \#97-01

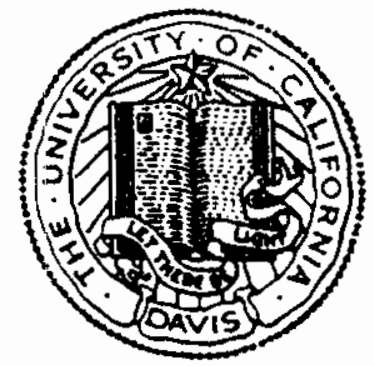

Department of Economics

University of California

Davis, California 95616-8578 


\title{
The Rhetoric of Friedman's Quantity Theory Manifesto
}

\author{
Thomas Mayer
}

Working Paper Series No. 97-01

January 1997

Vote: The Working Papers of the Department of Economics, Universin of California. Davis, are preliminam materials circulated to invite discussion and critical comment. These papers may be freels circulated but le. protect their tentate character the are not to be quoted without the permission of the author. 


\section{THE RHETORIC OF FRIEDMAN'S QUANTITY THEORY MANIFESTO}

\section{THOMAS MAYER*}

Friedman's (1956) essay "The Quantity Theory of Money: A Restatement" that appeared as the first chapter of his Studies in the Quantity Theory of Money set the agenda for a substantial part of the macroeconomic debate of the 1960s and 1970s. Laidler (1994, p. 4) refers to it as marking the beginning of the "Monetarist episode", even though it deals only with one part of the monetarist paradigm. Although in subsequent years Friedman wrote much on the quantity theory, this paper remains his best exposition of it. It is superior to his more detailed 1970 exposition because here, in contrast to his 1970 paper, he employs a theoretical framework that is congenial to him. and also hecause it is more closely related to his subsequent empirical work. 1

Its importance for the history of monetary thec $y$ is not the only reason this paper deserves study. Another is its expository technique. Friedman is one of the most accomplished expositors of our profession. A study of his rhetoric may therefore teach the rest of us how to present our work His 1956 paper is a particularly good example of his rhetorical skills because, as discused below. writing it presented an unusually challenging rhetorical task.

A third reason for studying Friedman's rhetoric is to elucidate the rhetoric of economics. Thus IMcCloskey (1985) has argued that we will become better economists if we understand what arguments persuade us and why. Robert Solow (1988). too. sees nothing but good coming from the study of how economists persuade each other. It is therefore not surprising that the rhetoric of tconomics has become a flourishing subfield. McCloskey (1994) list sixty-eight books and papers published in the period 1982 to 1994 that are concerned with the rhetoric of economics, though many ot them deal with this topic only peripherally.

This is not the first study of Friedman's rhetoric. Harry Johnson (1971) has studied the rhetoric and strategy of both the Keynesian and monetarist revolutions, and has much to say that is "elevant for Friedman's 1956 essay. And so does a recent paper by Roger Backhouse (1994). Both are discussed below.

It should be obvious that I am using the term rhetoric not in the pejorative sense of a shell game Ir an exposition that, while superficially persuasive is fundamentally flawed. Instead. [ follow 
McCloskey (1985 p. 29) who defined rhetoric as "the art of speaking [or] ... the study of how people persuade", and hence as a basic component of good science. All sciences, including mathematics (see Davis and Hersch. 1987) use rhetoric. As John Campbell (1987, p. 69) in his study of Darwin's rhetoric remarked: "Even scientific discourse must be persuasive to rescue insight from indifference, misunderstanding. contempt, or rejection." In this spirit when I suggest below that Friedman presented his argument in a certain way because that was an effective rhetorical device, I am not accusing him of departing from the highest standards of intellectual integrity. As long as one does not use an argument that one knows, or should know, to be flawed, it is entirely appropriate, and indeed an aid to the reader, to use that argument and exposition that will prove most effective. Moreover, I am not implying that Friedman consciously employed a certain mode of exposition because it is good rhetoric. A brilliant exfcsitor can do that without being aware of it

I. The Hegemony of Keynesian Theory

For two or three decades following the publication of Keynes' (1936) General Theor the quantity theory was usually treated as an outmoded approach.' As Laidler (1991, pp. 291-92) reports: "At no time in history was the quantity theory in greater disrepute than in the two decades following the second World War." Thus in 1951 Seymour Harris (p. 183) wrote that the relegation of monetary policy: "to a secondary role resis not only on history but also on the development of Keynesian economics. It is increasingly iashionable to attack the problem [of excess demand] through fiscal policy." Similarly, Lawrence Ritter (1959 p. 120) pointed out that: "the view has been widely expressed that anti-inflationary monetary policy is unlikely to be successful because of offsetting movements in velocity." Alvin Hansen (1957, p. 50), who was widely considered the leading American macro-economist of his generation wrote that:

I think we should do well to eliminate once and for all, the phrase 'velocity of circulation' from our vccabulary. Instead, we should simply speak of the ratio ot money to aggregate spending. The phrase velocity of circulation is, I feel, unfortunate because those who employ it tend to make an independent entity out of it and imbue it with a soul. "The little manikin is placed on the stage, and the audience is led to believe that it is endowed with the power of making decisions directing and controlling the flow of aggregate spending. In fact it is nothing of the sort. It is a mere residual. We should get on much better if we substitute the word 'ratio'. Thr: little manikin would then be forced back into oblivion where it properly belongs.

Similarly, in Britain the Radcliffe Committee stated: 
We have not made more use of this concept [velocity] because we cannot find any reason for supposing, or any experience in monetary history indicating, that there is any limit to the velocity of circulation: it is a statistical concept that tells us nothing directly of the motivation that influences the level of total demand. (Committee on the Working of the Monetary System, 1959, p. 133.)

By no means all economists went that far, and many did important work on the demand for money and velocity. Thus William Baumol (1952) and James Tobin (1956. 1958) developed models of the transactions and precautionary demands for money, while other economists did sxtensive empirical work on the demand for money. (See for instance. Doblin, 1951: Garvey 959: Tobin, 1947.) Moreover, in 1952 many prominent economists signed a statement, which while hardly a ringing affirmation of the quantity theory, did give some role to the quantity of tnoney: "The amount that individuals and businesses desire to spend is powerfully influenced both by the volume of credit that is available to them and by the volume of money and other liquid issets that they already possess." (Anonymous, 1952) And in the same year as Friedman's essay there appeared Don Patinkin's (1956) classic reworking of the quantity theory and of monetary theory in general. Moreover. as Johnson (1971) has pointed out the standard IS-LM model seems to imply a stable demand function for money.

But even those who considered the money demand function worth investigating, and allowed a certain role for monetary policy, generally did so within a Keynesian framework in which the supply of money is simply one of several variables that determine money income, and is far from being the most important one.

Such a strong conviction that the quantity theory was an outmoded theory presented Friedman with a difficult task. And so did the fact that as Laidler (1991) has pointed out, debates about the quantity theory have a strong ideological element. This makes it hard to persuade those on the other side of the debate. Moreover. many economists were skeptical of any work originating in the Chicago economics department, because they rejected its laissez-faire tradition.

\section{Methodology}

In his attack on the well entrenched Keynesian consensus (also called the neo-classical synthesis) Friedman greatly benefitted from a change in the profession's methodological preferences, a change for which he himself was in large part responsible. Three years earlier in his famous 
methodological paper (Friedman. 1953) he had argued that theories should be evaluated primarily by their ability to prediut, and not by the realism of their assumptions, or by their descriptive realism or by their concordance with personal experiences and similar types of casual empiricism. (See Hirsch and de Marchi, 1990.) Although Friedman's methodological essay has been much criticized by professional methodologists, it has had great appeal to other economists. (See Boland. 1979. p. 503)

This new methodology helped Friedman to build a case against the Keynesian consensus in several ways. First, any change in the methodological criteria for evaluating theories implicitly calls into question the validity of theories, such as Keynesian theory, that had been accepted on the basis of the previous criteria. Second, Keynesian theory had had an advantage over the quantity theory because its assumptions seem more realistic. The assumprions of the popular Keynesian multiplier-accelerator model, thar consumption depends on income and investment depends on the change in sales. seem highly credible. More generally. since most economists themselves are not severely capital rationed. it may seem natural to them that expenditures depend more on income than on money holdings. But Friedman's new methodology allowed him to shift the focus of the discussion from such casual empiricism and emphasis on assumptions to the question of how well the theory predicts. On this he could point to the empirical chapters of the book that. on the whole. offered successful predictions based on the quantity theory. Moreover, he could use his "as if" methodology to counter the complaint that the quantity theory is a "black box" that does not explain in nearly as much detail as the Keynesian theory. just how and why income changes. ${ }^{3}$ (See Johnson. 1971)

Backhouse (1994) has recently argued that any gain than Friedman derived from his seeming use of the "methodology of posiiive economics" is unwarranted, because Friedman did not really use that methodology. He argues that from a reading of Friedman's methodological essay one would expect Friedman to justify his theory by "providing evidence for the success of its predictions. perhaps with additional evidence concerning its simplicity, elegance and fruitfulness." What we find. however. appear's to be completely different (Backhouse, 1994 p. 189) Thus he reads Friedman's claim that his essay is founded on the Chicago tradition as an argument from 
authority. He also points out that what Friedman presents is more an approach than a testable theory. For example Friedman does not discuss the measurement problems arising from using permanent income in place of measured income, and from changes in the definition of money. And his "emphasis is on opinions and beliefs rather than on proof or demonstration." (Backhouse. 1994. P 187)

Backhouse is right if one considers Friedman's essay in isolation from the other work that he and his students have done on the quantity theory: and most of that work was published only subsequently. If so the essay does not resonate with Friedman's explicit methodological principles. or for that matter with his usual methodological practice. (See Hirsch and de Marchi, 1990.)

But when viewed in another context the inconsistency disappears. If one treats the essay as an intrnductory statement intended merely to whet the readers' interest in the quantity theory. and not as the presentation of a completed research project. then the deficiencies that Backhouse lists can readily be forgiven. The first chaprer of a book - and that is what Friedman's essay is - can legitimately discuss a general approach rather than a testable theory. and can present its conclusions in the form of opinions. Moreover. while an introductory chapter will often indicate the predicrive capability and fruitfulness of the theory by summarizing the results shown in subsequent chapters and Friedman does that - it will typically not present compelling evidence on these issues. It is also common for an introductory chapter to devote considerable space to the theory's provenance.

\section{Friedman's Response to the Challenge}

Despite the just discussed methodological advantage Friedman faced a daunting task in trying to induce economists to relinquish the Keynesian consensus, and to return to a theoretical approach which most of them had previously abandoned. His initial objective was therefore not to convince his readers that the quantity theory is necessarily correct. but that it is a theory that tnight be worth reconsidering. so that his paper is worth taking seriously.

One possible way to induce readers to reconsider a theory they had previously rejected, is to tell them right at outset that what they will find presented here is something that differs sharply from the old, stale doctrine that they had previously rejected. Hence, they can accept the new theory without incurring the embarrassment of having to admit that they had made a mistake when 
they previously rejected the quantity theory. Friedman does this by starting his essay as follows:

The quantity theory of money is a term evocative of a general approach rather than a label for a well-defined theory. The exact content of the approach varies from a truism defining the term "velocity" to an allegedly rigid and unchanging ratio between the quantity of money - defined in one way or another - and the price level ... [I]t is clear that the general approach [of the quantity theory] fell into disrepute ... and only recently has been slowly re-emerging into professional respectability. The present volume is partly a symptom of this re-emergence and partly a continuation of an aberrant tradition. Chicago was one of the few academic centers at which the quantity theory continued to be a central and vigorous part of the oral tradition. ... The quantity theory that retained this role differed sharply from the atrophied and rigid caricature that is so frequently described by the proponents of the new income-expenditure approach - and with some justice to judge by the much of the literature on policy that was spawned by quantity theorists. ... [N]o systematic statement of this theory as developed at Chicago exists. ... And this is as it should be, for the Chicago tradition was not a rigid system, an unchanged orthodoxy, but a way of looking at things. It was a theoretical approach that insisted that money does matter - that any interpretation of short-term movements in economic activity is likely to be seriously at fault if it neglects monetary changes and repercussions and if it leaves unexplained why people are willing to hold the particular nominal quantity of money in existence. The purpose of this introduction is nor to enshrine - or should I say inter - a definitive version of the Chicago tradition. (Friedman. 1956, p. 3)

This passage has been much criticized. Don Patinkin (1972, 1981. Chapters 10 and 11) and Harry Johnson (1962) argue persuasively that the theory that Friedman presents differs sharply from what had been taught at Chicago, and instead has Keynesian origins. In 1964 Friedman himself acknowledged a strong Keynesian influence on his formulation of the money demand function (Friedman. 1964). Even so, he maintains that it should be considered a development of the Chicago tradition. (See Friedman. 1972: and alsu Parkin, 1986) Others have criticized the above-cited passage because Friedman ignored work on the quantity theory done outside Chicago (See Humphrey, 1971; 1973; Tavlas, 1976: Patinkin, 1981, 1981. Ch. 11; Laidler, 1993.) A complication is that. as Tavlas (1997) points out. leading Chicago economists advocated public works expenditures as a way of getting additional money into circulation, thus advocating "Keynesian" policy for quantity-theory reasons. Despite these complexities I will refer to Friedman's theory as a quantity theory. in part because that need not imply that his essay is necessarily in the Chicago tradition, and in part because that is the phrase customarily used to describe his theory

Apart from the disputed issue of paternity a major (and entirely legitimate) purpose of this 
passage seems to be to shake the confidence of the reader in the belief that she already know all she need to know about the quantity theory to be able to reject it. ${ }^{4}$ So Friedman emphasizes that the quantity theory is a broad approach, a way of looking at the macro economy and not a specific Inodel that the reader previously rejected. To stress the difference between his approach and what one might call the naive version of the quantity theory Friedman writes that he accepts three standard and telling criticisms of the naive version: that it confuses the quantity theory, which is an ampirical theory, with the MV=PT identity, that it claims that velocity is numerically stable (a claim strongly rejected by the data during the Grea: Depression and World War II), and that it ignores the problem of defining money. By telling the reader: "yes, you are right to have rejected for these reasons the 'atrophied and rigid' version of the quantity theory," Friedman tells him that he is on his side. Moreover, by saying that the quantity theory is now re-emerging Friedman is sending a warning to any readers who might want to make herself seem up to date by disparaging the quantity theory.

Friedman's description of the Chicago quantity theory not as a finished theory, but as an evolving research program not only helps to overcome the natural reluctance to reconsider what one had previously rejected. but has an additional rhetorical advantage: it makes the theory look like a source of substantial research opportunities. And so does the inclusion in the book of four significant empirical studies. One need not be entirely committed to a public choice theorv of academia to conclude that a belief that a theory can be used to generate numerous papers makes that theory attractive to academics. In addition, as Johnson (1971) has pointed out. Friedman's analysis implies a shift of the research agenda away from large econometric models. That made the quantity theory appealing to young economists who can work on such models only as junior members of a team.

The disparaging tone of Friedman's discussion of the policy recommendations spawned by quantity theorists outside Chicago, while unfair to these quantity theorists, could also be expected to make the quantity theory attractive to most economists. ${ }^{5}$ It is a commonplace that part of thr enthusiasm for Keynesian theory in the 1930s and in the early postwar period was due to it providing intellectual support for policies that many economists found attractive for other reasons. 
Finally, by describing the quantity theory broadly as: "a theoretical approach that insisted that money does matter" and as an insistence on analyzing equilibrium in the market for money. Friedman makes it difficult for readers to say thct they reject the quantity theory. A subtle shift of focus accomplishes this task. A typical Keynesian of, say 1950 vintage would not deny that the money market must equilibriate, but would argue that as an empirical matter the effect of a change in the money supply on nominal income is very small, and that most of the observed changes in nominal income are the due to other factors. Reestablishing equilibrium in the money market even in the face of a substantial increase in the money supply results in only very small increase in income, because of a highly interest elastic demand for money and a highly interest inelastic marginal efficiency of investment. By stating - at an abstract level a basic principle of economics that the money market must be in equilibrium for $i$ come to be at its equilibrium level, Friednan by-passes this response, and induces the reader to be receptive to his message.

\section{Friedman's Choice of Paradigms}

An alternative way Friedman could have responded to the prevailing opposition to the quanticy theory is to have presented his analysis. not as part of the Chicago quantity theory, but as a modified version of Keynesian theory. He could have derived the standard quantity-theory results from a model with a high interest elasticity of expenditures and a low interest elasticity of a stable money demand function. and with there being greater shocks to the money supply than to the other

standard Keynesian variables, ${ }^{6}$ That would have justified focusing attention. as Friedman does. on the money market instead of on income-expenditure relations.

By doing so Friedman could have avoided asking his readers to abandon the paradigm they were familiar with. But the advantage of that should not be exaggerated. While the quantity theory and Keynesian theory are different paradigms in the lose sense of the term "paradigm" they are not different paradigms in the sweeping Kuhnian sense of the term. Roth deal with the same problem. determining nominal income, and by 1956 there was no longer any serious problem of communication. Even so. Friedman would have benefitted at least to some extent by presenting his work in Keynesian terms. Why didn't he?

One possible explanation is that. although he at one time accepted a part of Patinkin's 
argument that much of his essay is in an important way Keynesian (Patinkin, 1981, Chapter 11). that was not how he thought of it at the time he wrote his essay, and he did not $w_{\mathfrak{k}}$ nt to sail under false colors. ${ }^{7}$ Another possibility is that he was influenced by a sense of loyalty to his Chicago teachers and colleagues

A third possibility is that, as Johnson (1971) has suggested, in presenting a seemingly new theory it helps to absorb the valid parts of the old theory under "confusing new names". How plausible is this explanation? It is true that by making the demand for money a function of the interest rate the other Keynesian variables are allowed to enter by the back door, something that Friedman does not make explicit. But it is hard to see how Friedman, the author of a price-theory text, could have avoided including the rate of interest in the money demand function, and there is no reason to think that he believed that by introducing the Keynesian variables only indirectly he would make his essay more acceptable. 8

Another possible explanation is that he thought that if he presented his analysis as an outgrowth of Keynesian theory he would have found it hard to persuade Keynesians that it is a useful outgrowth. Keynesians would not have welcomed his positive heuristic of focusing on the market for money and letting the other Keynesian variables enrer only indirectly through their effects on the cost of holding money. That was alien to their research heuristics and would have devalued much of the work they had done since 1936.

In addition. Friedman would then have had to contend with the widespread view that the interest elasticity of expenditures is very low, while the interest elasticity of the liquidity preference function is high, and that both the liquidity preference function and the marginal efficiency of investment are unstable. ${ }^{9}$ Given the available econometric techniques it would have been extremely difficult for Friedman to make a convincing case.

Furthermore, Friedman's methodological preference is to evaluate theories by testing their central implications. He therefore preferred to test his theory not by testing assumptions about elasticities, but by the success his students had had in using it to explain a wide variety of events. Besides. Friedman is uncomfortable working with the simplistic IS-LM model that underlies tht: interest-elasticities approach.10 


\section{Friedman's Portfolio Analysis}

Friedman devotes about half his essay to developing the microfoundations for his money demand function, thus answering the objection that the quantity theory is mechanistic. that it reads as though money has a velocity of circulation that is independent of human volition and maximizing behavior. ${ }^{11}$ These microfoundations brought the quantity theory up-to-date. It is true they were nut rigorous enough to satisfy all economists (see Hahn, 1958). or nearly as elaborate and rigorous as those provided by Patinkin in the same year, nor would they be considered adequate by the prevailing standards of the $1990 \mathrm{~s},{ }^{12}$ But in the 1950s they did show that the quantity theory was a theory capable of sufficient refinement, and not just a vague common sense rationalization of some observed correlations.

By presenting his portfolio theory in som detail Friedman gained another. though perhaps unintended advantage. As he points out: "Almost every economist will accept the general lines of ... [this | analysis on a purely formal and abstract level" (Friedman, 1956, p. 15). With a large part of the essay thus being uncontroversial Friedman reduces some readers' potential feelings of antagonism to a paper by a Chicago economist who is advocating an "old fashioned" theory that has the unpleasant policy implication that fiscal policy is ineffective.

Friedman commences his portfolio analysis with a point that though obvious by hindsight had been largely ignored and that sets the stage for his detailed portfolio analysis: Since money is a capital good that provides a flow of services, the theory ot deinand for money can be subsurited under the general theory of demand for capital goods. This implies that one should be loath to talk about velocity being stable because payment habits and customs are stable. Habits and customs relating to transportation are also stable, but economists analyze the demand for cars by looking at relative prices and incone.

Friedtnan then introduces an innovation derived from his work on the permanent income theory. This is to expand the traditional concept of wealth to include human wealth. so that, given the rate of interest $u$ is arbitrary whether one uses wealth or income as the budget constraint. Although this is hardly a matter of great importance for the quantity theory. it is an elegant point likely to make readers appreciate the essay. 13 
After that Friedman sets out a portfolio balance model containing money, consols, short-term securities, equities, physical capital and human capital. and discusses the yields of these assets. Hc: then simplifies the analysis by taking the ratios of certain unobservable yields to observable yields as constant, so that he obtains the following demand function for nominal money 1) $\mathrm{M} / \mathrm{P}=\mathrm{f}\left(\mathrm{r}_{\mathrm{b}}, \mathrm{r}_{\mathrm{e}}, 1 / \mathrm{P}\{\mathrm{dP} / \mathrm{dt}\}, \mathrm{w}, \mathrm{YIP}, \mathrm{u}\right)$

where $\mathrm{M}$ is nominal money, $\mathrm{P}$ is the price level, $\mathrm{r}_{\mathrm{b}}$ and $\mathrm{r}_{\mathrm{e}}$ the yields on bonds and equities. $\mathrm{dP} / \mathrm{dt}$ the expected rate of inflation, $w$ the ratio of nonhuman to human wealth, Y income and $u$ tastes. From this he derives an equation for income $(\mathrm{Y})$

(2) $\mathrm{Y}=\mathrm{v}\left(\mathrm{r}_{\mathrm{b}}, \mathrm{r}_{\mathrm{e}}, 1 / \mathrm{P}\{\mathrm{dP} / \mathrm{dt}\}, \mathrm{w}, \mathrm{Y} / \mathrm{P}, \mathrm{u}\right) \mathrm{M}$.

3y writing the equation in this form Friedman makes it clear that he treats velocity as determined by maximizing behavior, and not by payment habits and institutions. He also makes it explicit that knowing the quantity of money does nor allow one to determine the equilibrium level of income unless one also knows the structure of interest rates and the level of real income.

In the following passage Friedman (1956. p. 15) explains, in anticipation of his work on the "missing equation" (Friedman. 1970), that: Even under the most favorable conditions, for example :hat the demand for money is quite inelastic with respect to the variables in v, equation ... [(2)] gives at most a theory of money income". anu does not tell us the breakdown of this change xetween prices and real income. Ar tirst glance the presence of the phrase "at most" is surprising. But it is needed to deal with a complication. Except in the special case in which the real income lasticity of demand for money is unity. when the quantity of money rises the increase in nominal Income required to restore equilibrium depends upon the breakdown of this increase in nominal income between prices and real income. ${ }^{14}$ By saying "at most" Friedman protects himself from rhe criticism that he has ignored a significant difficulty for the quantity theory, without having to take up a complication that reduces the quantity theory's ability to predict nominal income. ${ }^{15}$

\section{What Distinguishes the Quantity Theory from Keynesian Theory?}

Since the portfolio theory that makes up such a large part of the essay is essentially uncontroversial Friedman then asks what it means to say that somebody rejects the quantity theory. He mentions 
three points of contention between quantity theorists and Keynesians: "(i) the stability and importance of the demand function for money; (ii) the independence of the factors affecting demand and supply: and (iii) the form of the demand function or related functions." (Friedman, 1956. p. 15). He does not discuss explicitly two other disagreements.

One, which later played a central role in his debate with his critics (Friedman, 1972), is that in Keynesian theory either prices are: taken as rigid or at least as very slow to adjust. or else the analysis is applicable only to the early effects of an increase in the money supply. Perhaps he did not discuss this because in 1956 he had not yet worked it out.

The second disagreement that Friedman does not take up explicitly, is the difference in the research heuristics of the two theories. This difference is not relevant if one thinks about theories in the narrow sense of the term, as is frequently done in economics. and was probably even more common in 1956. when Thomas Kuhn's The Structure of Scientific Revolutions had not yet appeared. But it is likely that preference for one set of research heuristics over the other plays a significant implicit role in one's choice between the Keynesian and quantity theories. It seems plausible that Keynesian theory reaps an (unfair) advantage from an intuitive feeling that one's expenditures depend more on one's income than on one's money holdings. Moreover. there is the QWERTY problem. many economists had invested much intellectual capital in the Keynesian program. Hence. by not discussing research strategies explicitly Friedman reduce opposition to his essay. regardless of whether or not that was his motive.

Implicitly, however, the choice between Keynesian and quantity-theory research strategies shows up twice in Friedman's essay. One instance is that:

The quantity theorist not only regards the demand function for money as stable: he also regards it as playing a vital role in determining variables that he considers of great importance .... It is this that leads him to put greater emphasis on the demand for money than on, let us say. the demand for pins, even though the latter might be as stable as the former. It is not easy to state this point precisely, and I cannot pretend to have done so. (Friedman, 1956. p. 16)

Although. as Friedman says,, it may be hard to state precisely, the general ideas that money unlike pins directly enters every market. and that wages and prices are set in money terms. are points that the reader should find obvious and uncontroversial - unlike the idea that one can predict 
nominal income better by looking at the money supply than by looking at the standard Keynesian variables. The other place is Friedman's claim that the empirical studies included in his book show how fruitfully the quantity theory can be applied to macroeconomic problems.

On the first point of the three points of contention that he does take up Friedman (1956, p. 16) compares the quantity theorists' belief that the demand for money is stable with the belief that: "The demand for money ... is a will-0'-the wisp, shifting erratically and unpredictably with every rumor and expectation." Friedman does not explicitly call this belief "Keynesian", but since he attributes it to the 1930s the reader may easily get the impression that this is what Keynesian believe. And as the previous citations from Hansen and the Radcliffe Committee illustrate some Keynesians held such an extreme view. But it is not an adequate representation of the entire spectrum of Keynesian thinking, let alone of all anti-quantity-theory thinking. Thus. some Keynesians fitted demand function for money. or for what they considered the mostly volatile component of money, idle (or speculative) balances. using only the interest rate and not rumors and expectations. (See Brown, 1939; Kalecki. 1940; Tobin, 1947.)

Furthermore, Keynesian emphasis on the instability of the money demand function had decreased since 1936. It is likely that by 1956 Friedman's rejection of the will-0'-the wisp view seemed reasonable to the majority of Keynesians. Friedman should therefore have clarified that this point of contention is one between quantity theorists and what might be called extreme Keynesians. such as the post-Keynesian school. But Friedman might reply that he is not responsible if readers confuse his phrase "in the 1930's" (Friedman. 1956. p. 16) with present-day Keynesian theory.

Moreover. Friedman (1956, p. 16) also challenges the more moderate Keynesian position by writing that: "The quantity theorist accepts the empirical hypothesis that the demand for money is highly stable - more stable than functions such as the consumption function that are offered as alternative key relations." He points out that by stability he means not numerical stability, but a stable functional relation between the real quantity of money demanded and a few specified variables. This the shift of focus from numerical to functional stability is a main contributions of his essay.

But, as already discussed. functional stability, unlike numerical stability does provide a 
channel. the interest rate, by which other Keynestan variables can affect nominal income. Hence a functionally stable demand for money is only a necessary, but not a sufficient condition for the validity of Friedman's quantity theory. He does not discuss this problem, perhaps largely because of his methodological preference for testing theories by their implications and not by their assumptions. If it turns out that most of the observed changes in income can be explained by exogenous changes in the money supply, and not by the effect of changes in the interest rate on the demand for money, then the causes of changes in the interest rate are not so important. Not discussing this backdoor channel for Keynesian variables also has a rhetorical advantage since it simplifies the exposition, and avoids the need to defend the quantity theory at an addition point. a point at which it would have been hard to obtain convincing evidence either way.

The second point of contention relates to an isue that would later become central to the monetarist debate. the direction of causation between money and income. (See Hammond. 1996b.) Frjedman takes a moderate position. claiming only that causation runs from money to income some of the time:

"there are important factors affecting the supply of money that do not affect the demand for money. Under some circumstances these are technical conditions affecting the supply of specie: under others. political and psychological conditions determining the policies of monetary authorities and the banking system. (Friedman, 1956, p. 16.)

He then describes the real bills doctrine as "the classic version of the objection" to the quantity theory on the issue of direction of causation. ${ }^{16}$ In calling the real bills doctrine the classic objection Friedman is correct. and he also gains a rhetorical point. since the real bills doctrine is in very bad repute among monetary economists. But this is so mainly because of its normative element - that the money supply should change to accommodate changes in the demand for money rather than its prediction of how the money supply does behave. Hence reference to the real bills doctrine should not be considered a sufficient answer to the "reverse-causation" criticism. Moreover. the casual reader may confuse the "classic objection" with the strongest objection, and thus obtain a misleading impression of the seriousness of the reverse-causation problem.

However, Friedman does riot dismiss this problem merely by referring to the real bills doctrine. but goes on to say that there are important determinants of the money supply that arc 
independent of the demand for money. This makes it possible - for specific cases in which these determinants can be snown to operate t o test, as Friedman and Schwartz (1963) subsequently did. the quantity-theory hypothesis that when the money supply changes nominal income changes in a predictable way. But it does not provide a justification for a much stronger quantity-theory hypothesis: that most of the observed changes in nominal income are due to exogenous changes in the money supply. And it does not justify the practice, so common in the 1960s and 1970s, of interpreting a good fit in a regression of income on the money supply as a confirmation of the quantity theory. While Friedman does not deny that, it is something that a hasty reader of his essay may overlook

Friedman's third point of contention is the slope of the liquidity preference function

The attack on the quantity theory associated with the Keynesian underemployment analysis is ... [that the] demand for money, it is said, is infinitely elastic at a "small" positive interest rate. At this interest rate, which can be expected to prevail under under-employ men^: conditions, changes in the real supply of money ... have no effect on anything. (Friedman, 1956, p. 17.)

This is a point where Friedman's rhetoric is bad because he does not state his argument clearly and unambiguously. On the one hand, the just cited passage could be read simply as a descriptive statement about what Keynesians believe (or perhaps what Keynes himself believed in 1936). without this being a necessary condition for the validity of Keynesian theory. If this is all that Friedman intends it is puzzling why he singled it out as one of three points of contention.

Alternatively, because of the prominent position that Friedman gives it, one might read it as meaning that unless the interest elasticity of demand for money is infinite Keynesian theory is invalid. But if that is what he intends, how can he expect the reader to understand this argument without detailed explanation? In a classic paper Tobin (1947) had argued that the quantity theory (classical economics) is valid if. and only if, the demands for money is completely interest inelastic, while Keynesian theory is valid both if the demand for money is infinitely elastic and if it has a finite, but nonzero (negative) elasticity. Friedman should have expected many, of his readers to be familiar with Tobin's position and to have accepted it. Yet he does not offer an explicit response, such as Tobin's failure to take price changes and wealth effects into account. He should therefore have expected that readers would find his position puzzling rather than persuasive. 
Why then did he not explain his position? One can only conjecture. One possibility is that he had not yet worked out sufficiently the analysis he would present in subsequent papers (Friedman. 1970, 1972). This is that. unless the interest elasticity of demand for money infinite. an increase in the quantity of money initially lowers interest rates at least slightly. This results in an increase in expenditures until prices have risen enough to bring the real quantity of money back to its previous level. And that requires as the quantity theory predicts. that prices have risen in proportion to the quantity of money. Only if the interest elasticity of demand for money is infinite, or if prices are fixed does this process not occur. (For a further discussion see Mayer, 1976) But Friedman should not have expected the reader to understand an analysis that he would not present until many years afterward.

Moreover, is Friedman correct in claiming that to have a coherent theory Keynesians must assume that the demand for money is infinitely elastic. so that Keynesian theory is a special case'! Instead. they can assume that, over the relevant horizon, prices are sticky. That is a common featurr of Keynesian models. Hence. Friedman should in this essay have tried to justify his unconventional reading of Keynesian economics.

He does so in a subsequent paper (Friedman, 1972), responding to Patinkin's (1972) criticism. There he cites numerous passages from the Cieneral Theory in support. But it is doubtful that these support his claim. ${ }^{17}$ And even if in 1936 Keynes had assumed that the liquidity preference functior is infinitely elastic. this does not mean that Keynesian economists in 1956 did so ton ${ }^{18}$ As already mentioned. Tobin (1947) explicitly identified Keynesian theory with any negative interest elasticity. And already in the early years of the Keynesian revolution when Brown (1993) and Kalecki (1940) fitted liquidity preference functions and obtained downward sloping curves. they did not remark that this was inconsistent with Keynesian theory.

Given these problems with the third point of contention one should ask why Friedman took it up at all. Again, one can only conjecture. Perhaps it is because he believed that readers would object if he did not discuss the interest elasticities. Previously there had been much discussion about whether Keynes' basic innovation was the "discovery" of the interest elasticity of liquidity prctcrence, or his assumption of wage and price inflexibility. By 1956 it should have been clear to 
everyone that to the extent it was either. it was the latter. (See Patinkin, 1948) But the degree of wage and price flexibility required to reduce unemployment depends, in part, on the interest elasticities of liquidity preference and of expenditures. Hence these interest elasticities are of much interest even if they are not fundamental

\section{Friedman's Concluding Section}

Saying that "the proof of the pudding is in the eating" Friedman then discusses the empirical chapters of the book, which apply the quantity theory to various situations. Eugene Lerner explains intlation in the Confederacy, and Phillip Cagan explains hyperinflation. something that had previously been considered outside the scope of the quantity theory. And Richard Selden shows that velocity in the U.S. has been a stable function of a few variables over a long period. Only German inflation during World War II resists a fi ly satisfactory explanation by the quantity theory, and that can be accounted for by the Draconian system of price control

Toward the end of the book Friedman makes a strong claim:

One of the chief reproaches directed at economics as an allegedly empirical science is that it can offer so few numerical "constants", that is that it has isolated so few fundamental regularities. 'The field of money is one of the chief examples one can offer in rebuttal: then: is perhaps no other empirical relation in economics that has been observed to recur so uniformly under so wide a variety of circumstances as the relation between substantial changes over short periods in the stock of money and in prices; the one is invariably linked with the other and is in the same direction: this uniformity is, I suspect, of the same order as many of the uniformities that form the basis of the physical sciences.

This passage provides the reader with powerful motive to reconsider the quantity theory. And given the prevailing Keynesian consensus such a powerful motive was needed, both because of the substantial effort required, and because of a natural reluctance to change one's mind. But subsequently it has been cited gleefully by Keynesians who point to the high monetary growth rate that accompanied the falling inflation rate of the 1980s. (See, for instance, Benjamin Friedman and Kenneth Kuttner, 1992.) Whether that experience really does invalidate the above passage depends on how one interprets the word "substantial". If Friedman meant with it an annual growth rate of. say 20 percent. then it has yet to be disconfirmed. Friedman's statement seems startling and provocative. but is so vague that it: has little content. 


\section{Conclusion}

The preponderance of a moderate Keynesian consensus in the 1950 shaped the way Friedman presented the case for the quantity theory. His primary task had to be to convince economists to reconsider this theory. This required an ecumenical presentation that would not drive off potential readers who were committed Keynesians. At the same time it required making some strong claims for the quantity theory to provide a sufficient incentive to reconsider it. A combination of "sweet reason" and shock tactics was needed. Friedman succeeded brilliantly in this rhetorical task. And he did so in way that made it hard for his opponents to reasonably claim that he was employing "rhetoric" in the derogatory sense of the term. Nothing in his essay indicates that he followed Keynes (1924, p. 427) who tells us in his Treatise on Probability: "In writing a book of this kind the author must, if he is to put hi!; point of view clearly, pretend sometimes to a little more conviction than he feels. He must give his argument a chance, so to speak. not be too ready to depress its vitality with a wet cloud of doubt."

\section{ENDNOTES}

*. I am indebted for helpful comments to Milton Friedman and Matthew Rafferty

1. In his 1970 paper Friedman tried to accommodate the demands of his critics that he state his implicit model by reformulating his analysis in an IS-LM framework. This framework is uncongenial to him since it takes prices as fixed (and hence does not distinguish between nominal and real interest rates). and because it assumes that money is a substitute only for bonds and not for commodities. Apart from that unsuccessful attempt to communicate with his critics Friedman added only two major theoretical element in his subsequent writings on the quantity theory. One is the vertical Phillips curve. The other is that price flexibility ensures that changes in the nominal quantity of money do not lead to permanent or even long-run changes in the real quantity of money. (Friedman, 1968, 1972)

2. This does not necessarily mean that a majority if all economists had become Keynesians. Since a large proportion of economists at that time did not publish, their views are largely unknown. But among those who did publish the Keynesian paradigm ruled. Here are some anecdotes to illustrate its dominance. When as a graduate student in 1948-50 I had to read a book on macro I would check the index to see how often Keynes was mentioned. If there were only a few citations I was reluctant to read the book. In the summer of 1956 I taught a graduate macro course, using as a text Friedman's Studies in the Quantity Theory of Money, which had been published a few months earlier. When I asked students to comment on the: course one student responded that I should have used a more up-to-date text. Some time after that I was talking to a colleague when a student from my graduate monetary theory course came up and asked a question about the quantity theory. My colleague was surprised and asked me "who is still teaching the quantity theory?"

3. In this context the term "prediction" should be interpreted broadly as referring not just to forecasting some magnitude, such as the price level, but also to the theory's quantitative implications. This greatly reduces the distinction between prediction and explanation. Much of Friedman's 
essay is concerned with relating the demand for money, and hence the quantity theory, to the general theory of demand for durable goods, and thus with "explaining". But the acid test to Friedman is whether the theory predicts sufficiently well.

4. This purpose is also served by the next paragraph in which Friedman writes that: "the quantity theory is in the first instance a theory of the demand for money. It is not a theory of output, or of Inoney income or the price level." (Friedman, 1956, p. 4) This passage probably surprised many readers (it certainly did me) and hence undermined the reader's belief that she already knew what the quantity theory is. Friedman's statement is correct because it is qualified by the phrase "in the first instance", but traditionally the quantity theory had been considered a theory of the price level or Inoney income. Johnson (1971, p. 10) points out that calling the quantity theory a theory of the demand for money shields it from the criticism that it assumed that the economy automatically returns to full employment, "which was manifestly in conflict with the facts of experience." But the full employment assumption, while part of long-run classical theory, is not part, or at least not a prominent part of the quantity theory. The business cycles that Fisher (1922, Ch. 4) described showed unemployment that was consistent with experience.

5. Subsequently Friedman (1972) explained that he had in mind the policy recommendations of economists at the LSE in the 1930s. But neither of the two senior economists at the LSE was a quantity theorist. Friedrich von Hayek (1931) devoted an entire chapter to a criticism of the quantity theory, while Lionel Robbins (1934) was also critical of a quantity-theory explanation of fluctuations. By contrast, leading quantity theorists, such as Irving Fisher and Clark Warburton advocated policies much more in line with Friedman's.

t. That may seem contrary to Friedman's insistence on using the quantity of money instead of the rate of interest as the central variable. But Friedman does so for a practical reason, the difficulty of measuring the theoretical term "the rate of interest", and this is not relevant for the theoretical issues ciscussed in his essay. Friedman could also have obtained the main quantity-theory results by assuming more price flexibility than Keynesians did. 7. Nor is it the way Friedman thinks of it now. He now regrets his "offhand comment" to Patinkin on the Keynesian origins of his theory, a comment resulting more from "friendliness and fundamental disinterest in origins as opposed to cutcomes than any serious consideration of the origin of ideas." (Friedman, 1996)

7. The Chicago school has a strong sense of loyalty

$\varepsilon$. Johnson (1971, p. 9) also writes that it helps to introduce old concepts under "confusing new rames", and cites as instances the substitution of permanent income for wealth, and the "dragging across the trail of the red herring of human capital." But the term "permanent income" is sufficiently well explained by Friedman, and ecen if it might have been confusing in 1956 the publication of $A$ Theory of rhe Consumption Function the next year made it familiar to economists. Nor does the concept of human capital seem confusing.

9. For surveys of the literature on the interest elasticity of business investment see Meyer and Kuh (1963, pp. 340-41) and Eisner and Strotz (1963, pp. 227 and 232). Studies of residential construction attributed substantially greater importance to the interest rate (see Grebler and Maisel, 1963. pp. (608-609), but even so, this sector was not considered as interest sensitive then as it was later thought to be when Regulation Q became a serious constraint on intermediation. The response of consumption to interest rate changes was considered "negligible" (Suits, 1963, pp. 40-41) 10. It is also possible that Friedman saw little benefit from phrasing his discussion in Keynesian language. Clark Warburton (1946) had used Keynesian language to present a quantity-theory criticism of Keynesian theory on empirical grounds, and his paper was largely ignored. For a discussion of Warburton as a predecessor of Friedman see Cargill (1979).

11. The Cambridge version of the quantity theory (Pigou, 1917) was less subject to this criticism than the transactions version since it did provided some microfoundations, but these were not 
worked out in the more precise and detailed way that had become popular by the 1950s. Moreover. in the U.S. the transactions version predominated. For its time Pigou's (1917) exposition was extraordinarily sophisticated. He not only included in the cost of holding money expected inflation. but also made allowance for a money substitute. trade credit, reducing the demand for money, as well as for lagged money holdings having a positive effect on current holdings.

12. The microfoundations that Friedman provided were not as elegant as those that Baumol (1952) and Tobin (1956) provided for the transactions demand, and Tobin (1958) for the speculative (or it is sometimes asserted the precautionary) demand. But while the Baumol-Tobin microfoundations are better suited for microeconomic work, Friedman's are better suited for macroeconomics with its greater emphasis on measurability (see Hammond, 1996a) and prediction.

13. On the assumption that the ratio of human to nonhuman wealth is constant the possibility of switching between wealth and income is convenient for Friedman. Since he stresses the store-ofwealth function of money he should use wealth and not income as the budget constraint in his money demand function. But the available data do not measure wealth as accurately as income, and also it is changes in nominal income, not changes in wealth, that Friedman wants to explain.

14. Suppose the money supply increases by 10 percent, and that the real income elasticity of demand for money is 0.5 . Ceteris paribus equilibrium requires a 10 percent rise in nominal income if real income is constant and only prices rise, but a 20 percent rise in nominal income if prices are constant and only real income rises. For long rui analysis one can respond to this problem by claiming that over the long run unemployment is at the natural rate so that real income is constant.

15. It is not clear how important this complicaticn is. To an academic economist concerned with predicting or explaining changes in nominal income it is very important. But a policy-maker is more likely to be concerned with predicting real income and prices separately than with predicting nominal Income.

16. The real bills doctrine (already found in the Wealth of Nations) stated that as long as banks issue bank notes or loans only to finance real (i.e. not speculative) activity they will not be issued to excess since the increased demand created by additional bank notes or loans will be met by an increased supply of goods and services. Any excess bank notes issued will be returned to the banks since the public will not want to hold them. The same is true for bank credit. Hence, as long as banks avoid lending for speculative activity the central bank should let the supply of money and bank credit expand or contract in accordance with the demand for it.

17. For example. the first passage Friedman (1972. p. 945, emphasis added) cites is: "Circumstances may develop in which even a large increase in the quantity of money may exert a comparatively small influence on the rate: of interest." First. "may" is not the same as "does". and more importantly "comparatively small" is not the same as "no".

18. In a subsequent paper (Friedman, 1964) wrote that many Keynesians now think that it is only seldom that liquidity preference is absolute. 


\section{References}

Anonymous (1952) "iNonetary Policy to Combat Inflation." American Economic Review, vol. 42, June. pp. 384-91.

Hackhouse, Roger (1994) Interpreting Macroeconomics,, London, Routledge

Baumol, William (1952) "The Transactions Demand for Cash: An Inventory-Theoretic Approach," Quarterly Journal of Economics, vol. 66, November, pp. 45-66.

Boland, Lawrence (1979) Journal of Economic Literature, vol. 17, June, pp. 503-22

Brown, Arthur (1939) "Interest, Prices and the Demand Schedule for Idle Money," Oxford Economic Papers vol. 2, May, pp. 46-69.

Campbell. John (1987) "Charles Darwin: Rhetorician of Science," in J. Nelson. A. Megill and D. McCloskey (eds.) The Rhetoric of the Human Sciences. Madison, Univerity of Wisconsin Press.

Cargill, Thomas (1979) "Clark Warburton and the Development of Monetarism since the Great Depression," Historv of Political Econornv, vol. 1I, Fall. pp. 425-49.

Committee on the Workings of the Monetary System (1959) Report. London H.M. Stationary Office.

Davis. Phillip and Hersch. Reuben (1987) "Rhetoric and Mathematics," in J. Nelson, A. Megill and D. McCloskey (eds.) The Rhetoric of the Human Sciences, Madison. Univerity of Wisconsin Press.

Doblin, Ernest (1951) "The Ratio of Income to Money Supply: An International Survey." Review of Economics and Statistics, vol. 33, August, pp. 201-213.

Eisner, Robert and Strotz Robert (1963) "Determinants of Business Investment," in Commission on Money and Credit, Impacts of Mbnetan Policy, Englewood Cliffs, N.J.. Prentice-Hall.

Fisher. Irving (1922) The Purchasing Power of Monev, New York. Macmillan.

Friedman, Benjamin and Kuttner, Kenneth (1992) "Money, income. Prices, and Interest Rates." imerican Economic Review, vol, 82, June, pp. 472-492.

Friedman, Milton (1956) Studies in the Quantity Theory of Money, Chicago. University of Chicago Press.

Friedman, Milton (1957) A Theory of the Consumption Function, Princeton, Princeton University Press.

Friedman, Milton (1964) "Post-War Trends in Monetary Theory and Policy." National Banking Review. vol. 2. September, pp. 1-10.

Friedman, Milton (1968) "The Role of Monetary Policy," American Economic Review, vol. 58. March. pp. 1-17.

Friedman, Milton (1970) "A Theoretical Framework for Monetary Policy." Journal of Political Economy. vol. 78, March/April, pp. 193-238. 
Friedman. Milton (1972) "Comments on the Critics." Journal of Political Economv. vol. 80 September/October. pp. 906-650.

Friedman, Milton and Schwartz. Anna (1963) A Monetary History of the United States. Princeton, Princeton University Press.

Garvey, George (1959) "Structural Aspects of Money Velocity.". Quarterly Journal of Economics, vol. 73, August. pp. 529-35

Grebler. Leo and Maisel, Sherman (1963) "Determinants of Residential Construction." in Commission on Money and Credit, Impacts of Monetary Policy. Englewood Cliffs, N.J. Prentice-Hall.

Hahn. Frank (1958) Review of Studies in the Quantity Theory of Monev. Econometrica, vol. 26. July. pp. 476-79

Hammond, Daniel (1996a) "Labels and Substance: Friedman's Restatement of the Quantity Theory." unpublished manuscript.

Hammond, Daniel (1996b) Theory and Measurement, London, Cambridge University Press

Hansen. Alvin (1957) The American Economy. New York. McGraw-Hill

Harris. Seymour (195I) "The Controversy over Monetary Policy." Review of Economics and Statistics. vol. 33. August, pp. 179-84

Hayek. Friedrich von (1931) Prices and Production, London. Routledge Hirsch. Abraham and de Marchi, Neil (1990)Milton Friedman. New York. Harvester Wheatsheaf.

Humphrey. 'Thomas (1971) "The Role of Non-Chicago Economists in the Evolution of the Quantity Theory in America," Southern Economic Journal, vol. 38, July. pp. 12-18.

Humphrey, Thomas (1973) "On the Monetary Economics of the Chicagoans and Non Chicagoans: Reply." Southern Economic Journal,, vol. 39, January, pp. 400-402.

Johnson. Harry (1962) "Monetary Theory and Policy." American Economic Review, vol. 52 June. pp 33584

Johnson, Harry (1971) "The Keynesian Revolution and the Monetarist Counter Revolution American Economic Review, vol. 61, May, pp 113

Kalecki, Michael (1940) "The Short-term Rate and the Long-term Rate,"Oxford Economic Papers. vol. 4, September, pp. 15-22.

Keynes. John M. (1924) A Treatise on Probability. London, Macmillan

Keynes. John M. The General Theor of Employment, Interest and Money. London Macmillan. Laidler, David (1991) "The Quantity Theory is Always and Everywhere Controversial Why'?" Economic Record. vol. 67, December. pp. 289-306.

Laidler, David (1993) "Hawtrey, Harvard and the Origins of the Chicago Tradition." Journal of Political Economy. vol. 101. December, pp. 1068-1103.

Laidler, David (1994) "Monetarism circa 1970 - a View from 1994," unpublished manuscript. 
Press.

McCloskey, Donald (1985) The Rhetoric of Economics,, Madison. University of Wisconsin

McCloskey, Donald (1994) "How to do a Rhetorical Analysis and Why." in Roger Backhouse, New Directions in Economic Methodology, London, Routledge.

Mayer, Thomas (1976) "The Interest Rate Snap-Back and its Implications for the Keynesian Quantity Theory Dispute." Banca Nazionale del Lavoro Quarterly Review, September. pp. 203.221 .

Meyer, John and Kuh. Edwin (1957) The Investment Decision, Cambridge MA.. Harvard University Press.

Parkin, Michael (1986) Review of Essays on and in The Chicago Tradition, Journal of Money. Credit and Banking, vol. 18, February. pp. 104-16.

Patinkin, Don (1948) "Price Flexibility and Full Employment," American Economic review, vol. 38, September, pp. 543-64.

Patinkin. Don (1956) Mona.. Interest and Prices, New York. Harper and Row.

Patinkin, Don (1872) "Friedman on the Quantity Theory and Keynesian Economics." Journal of Politicai Economy. vol. 80. September/October. pp. 885-905.

Patinkin. Don (1981) Essays on and in the Chicago Tradition, Durham. Duke University Press

Pigou. Arthur (1917) "The Value of Money." Quarterly Journal of Economics, vol. 32.

November. pp. 38-65.

Kitter. Lawrence (1959). "Income Velocity and Anti-Inflationary Monetary Policy." American Economic Review. vol. 49. March, pp. 120-29

Robbins, Lionel (1934) The Great Depression. New York, Macmillan

Solow, Robert (1988) "Comments from Inside Economics," in Klamer A., McCloskey, D. and Solow. R. The Consequences of Economic Rhetoric, New York, Cambridge University Press.

Suits. Daniel (1963) "The Determinants of Consumption Expenditures: A Review of Present Knowledge." in Commission on Money and Credit, Impacts of Monetary Policy, Englewood Cliffs, N.J., Prentice-Hall.

Tavlas, George (1976) "Some Further Observations on the Monetary Economics of Chicagoans and Non-Chicagoans." Southern Economic Journal. vol. 4, April, pp. 685-92

Tavlas, George (1997) "Chicago. Harvard and the Doctrinal Foundation of Monetary Economics." Journal of Political Economv, vol.105. p p. 185-209.

Tobin, James (1947) "Liquidity Preference and Monetary Policy,", Review of Economics and Statistics, vol. 29, May, pp. 508-16

Tobin. James (1956) "The Interest Elasticity of the Demand for Cash," Review of Economics and Statistics, vol. 38. August. pp 241-47.

Tobin. James (1958) "Liquidity Preference as Behavior towards Risk," Review of Economic 
Studies, vol. 25, February, pp. 65-86.

Warburton, Clark (1946) "The Misplaced Emphasis in Contemporary Business-Fluctuation Theory," Journal of Business, vol. 19, October, pp. 199-220. 